\title{
DESCRIPTION OF A NEW FOSSIL SEA COW FROM FLORIDA, METAXYTHERIUM FLORIDANUM.
}

\author{
By Oliver P. Hay. \\ Associate of the Carnegie Institution of Washington.
}

In the United States National Museum is a part of the upper right maxilla of a sirenian which is of great interest. It was received along with other specimens by Mr. George C. Matson, of the United States Geological Survey, in 1911, and is recorded as having been found 1 mile west of Mulberry, Florida, in pit No. 7 of the Prairie Pebble Phosphate Co. Matson figured this bone ${ }^{1}$ under the name "manatee." In the catalogue of the United States National Museum the specimen has received the number 7221. The fragment presents the hinder part of the right maxillary (pl. 1, figs. 1-3), extending from its articulation with the palatine forward to the front of the sockets for the anterior molar present. Near the front end, on the outer side of the bone, is a break which represents the base of the process which passed outward to join the malar bone. The maxilla is solid and heavy and has suffered little erosion. The fragment contains the hindermost molar tooth and the sockets, mostly filled by the roots, of three other molars. An examination of the specimen shows that it is closely related to the species which have been arranged under the genus Metaxytherium. The fragment of the maxilla (pl. 1, figs. 1-3) has a total length of $106 \mathrm{~mm}$. The width at the middle of the penultimate molar is $40 \mathrm{~mm}$. ; the height at the same place, $39 \mathrm{~mm}$. The whole base of the malar process is present and it had a fore-and-aft extent of about $44 \mathrm{~mm}$. Its thickness was greatest behind and amounted to about $18 \mathrm{~mm}$. Toward the front the process thinned out to a sharp edge.

As already stated, there were originally present four molars (pl. 1, fig. 3). The hindermost one is almost entire and is but little worn. Of the two immediately in front of it there are present only the roots; of the next one, only the sockets; and of the sockets of this

${ }^{1}$ Bull. No. 604, U. S. Geol. Surv., pl. 12 , figs. $A, B$.

No. 2438-Proceedings U. S. National museum, Vol. 6I, Art. 17. 
molar only a part of the outer front one is present, the bone in front of it being gone. The total length of the tooth line was close to $85 \mathrm{~mm}$. The first molar appears to have had its transverse axis turned so as to make an angle of about $45^{\circ}$ with the tooth line, the inner end being turned backward so that the inner root is opposite the front and outer root of the second molar. From the outer border of the outer and hinder socket to the inner border of the inner socket is a distance of $22 \mathrm{~mm}$. The roots of the second molar are present in their sockets. Evidently this tooth and the succeeding one were in the jaw when it was exhumed. This second molar has three roots, as the other molars, two outer ones and one inner. The distance across its outer sockets is $19 \mathrm{~mm}$., that across the outer sockets of the third molar is $22 \mathrm{~mm}$; and this seems to have been the length of the crown of this tooth. The tooth appears to have had a width of about $25 \mathrm{~mm}$. The roots of the hinder molar are large. The outer anterior is wholly hidden. The outer hinder root sent its extremity through the bone at a distance of $31 \mathrm{~mm}$. from its base (pl. 1, fig. 2). The inner root is exposed nearly its whole length on the inner face of the bone (pl. 1, fig. 1). It has a length of $40 \mathrm{~mm}$. and a diameter of about $13 \mathrm{~mm}$. at its base.

The crown of the hinder molar has lost a little of its enamel in a few places; but the loss has not seriously injured it. Its length is $26.5 \mathrm{~mm}$; its width, $25 \mathrm{~mm}$. It had only just begun to suffer wear. It presents essentially the characters of the genus Metaxytherium, as these have been expressed by Abel. ${ }^{2}$ Figure 4 of plate 1 represents the tooth with the cones restored so as to show their positions.

The enamel of the tooth is strongely wrinkled. Running across the tooth about the middle of the length is a deep valley. Its course is not direct, but from the outer side it runs slightly forward in front of the metaconule and then swerves slightly backward as it passes to the inner side of the tooth. The valley is most widely open near its outer end, but it is narrowed at its immediate entrance by a little accessory conule attached to the base of the metacone. On the other hand, there are no accessory conules to block up the inner end of the valley, such as Abel has represented in his figure 17 on his page 149. The protocone, the protoconule, and the paracone stand in a straight transverse row. The paracone and the protoconule are very close to each other. The former is somewhat larger than the latter. The summit of the protocone is worn down and the probable shallow notch between it and the protoconule has been effaced. There is a large anterior talon; and, on the outer half of the crown, this is separated from the paracone and the protoconule by a wide and deep valley. The outer half of the talon is narrow

2Abel, Abh. Geol. Reichsanst., Wien, vol. 19, Heft. 2, pp. 148-151. 
and sharp, but it widens toward the lingual side of the tooth and becomes broadly confluent with the protocone. If there was originally a valley between the talon and the protocone, it has disappeared through wear.

The metaconule occupies a central position in the tooth, behind the transverse valley. It is closely connected with the hypocone, apparently less closely with the metacone. It exceeds the latter in size. In M. krahuletzi, according to Abel's figure, it is smaller than the metacone. The hypocone is large. At the rear of the tooth, closing the gap between the hypocone and the metacone, are two accessory conules, and there is another behind and outside of the hypocone. Bounded by these behind and by the hypocone, metaconule, and the metacone in front and at the sides, is a considerable pit. In the European species of Metaxytherium just mentioned this is filled with small accessory tubercles. The base of the tooth seems to be covered with a considerable coat of cement and this spreads upward in a thin layer on the crown, especially in the valleys.

This tooth differs from the teeth of all the species of Metaxytherium figured by Abel in being broader in proportion to its length.

Nothing is known about the abundance of this species. In collections made from the phosphate deposits about Charleston, South Carolina, portions of the skulls and limb bones of sirenians are not rare. They appear to belong to more than one species and probably to more than one genus. It is, however, at present impossible to correlate any skull bones or limb bones with the jaw above described.

It is impossible to determine with accuracy the geological age of this species. It belonged probably either to the Upper Miocene or to the Lower Pliocene. The European species belong to the Miocene or in part to the Oligocene. According to Sellards ${ }^{3}$ the pebble phosphate beds at Mulberry rest on phosphatic marls of supposed Upper Oligocene age, and have been derived from the latter by reworking and concentration. The fossil here described is therefore probably residual from the parent formation, the Upper Oligocene.

From $\mathrm{Mr}$. Charles T. Earle, there has been lately received a considerable lot of fossil bones and teeth which had been washed up on the beach at Palma Sola, Manatee County, Florida. Among these remains are teeth and bones of horses, camels, bisons, Elephas columbi, etc. These belong certainly to the Pleistocene. Other bones and teeth are present, which appear to belong to Miocene or Pliocene deposits. Such are teeth of Carcharodon megatodon, $C$. auriculatus, Hemipristis serra, Lamna cuspidata, a part of the beak of a platanisted porpoise, and a tooth of a sea cow. There are

Fla. Geol. Surv., vol. 7, pp. 52-84. 
besides some bones of land tortoises and a part of a metapodial of a camel; but these may belong to the Pleistocene.

The sirenian tooth is of such a size and structure that it may well have belonged to the species of animal that possessed the upper jaw and teeth above named Metaxytherium floridanum. This tooth is apparently a lower right third molar, and it is well worn (pl. 1, fig. 5). The length is $25.5 \mathrm{~mm}$. The width in front is $20 \mathrm{~mm}$. There are present two well-preserved roots. The anterior occupies the width of the crown in front. On the outer side the cleft between it and the hinder root is somewhat behind the middle of the length; on the inner side, considerably farther in front. The hinder root is compressed from-side to side. Unfortunately the enamel is much broken away from the outer face of the tooth and somewhat less from the inner face. At the front of the tooth there appears to have been a deep valley, which extended backward between the protoconid and the other elements of the front crest. This valley has been worn quite to its bottom. Evidently it limited posteriorly the strongly developed anterior cingulum.

There appears to have been an accessory cusp at the base of the metaconid, on its buccal side. The valley which separates the two principal crests is seen to extend half way across the tooth from the inner side.

On account of the heavy wear there are not seen any remains of accessory cusps where the transverse valley opened out on the outer face of the tooth. For the same reason the exact structure of the hinder talon can not be determined by the writer; but this talon is well developed and there were two or three accessory conules.

This tooth is provisionally referred to the species Metaxytherium floridanum.

\section{EXPLANATION OF PLATE.}

\section{Metaxytherium floridanum, new species.}

Figs. $1-3$. Part of right side of upper jaw. $\times 3 / 4$. Type,

1. View of lingual face.

2. View of buccal face.

3. View of alveolar face showing hindermost molar and the roots and sockets of three other teeth.

4. Hindermost molar restored. $\times 1 . c^{1}$, anterior cingulum; $c^{2}, c^{2}$, three conules belonging to hinder cingulum; hy, hypocone; me, metacone; $m l$, metaconule; $p a$, paracone ; $p l$, protoconulus ; $p r$. protocone.

5. Lower right hindermost molar of a referred specimen. $\times 1$. 


\section{$2 \mathrm{BHL}$ Biodiversity Heritage Library}

Hay, Oliver Perry. 1922. "Description of a new fossil sea cow from Florida, Metaxytherium floridanum." Proceedings of the United States National Museum 61(2438), 1-4. https://doi.org/10.5479/si.00963801.61-2438.1.

View This Item Online: https://www.biodiversitylibrary.org/item/31797

DOI: https://doi.org/10.5479/si.00963801.61-2438.1

Permalink: $\underline{\text { https://www.biodiversitylibrary.org/partpdf/20203 }}$

\section{Holding Institution}

Smithsonian Libraries

\section{Sponsored by}

Smithsonian

\section{Copyright \& Reuse}

Copyright Status: NOT_IN_COPYRIGHT

This document was created from content at the Biodiversity Heritage Library, the world's largest open access digital library for biodiversity literature and archives. Visit BHL at https://www.biodiversitylibrary.org. 